\title{
Reservoir characteristics of the Miocene age formations at the Allas Dome, Hamrin Anticline, Northern Iraq
}

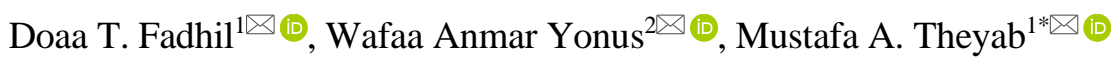 \\ ${ }^{1}$ University of Samarra, Samarra, 34010, Iraq \\ ${ }^{2}$ Salahuddin Education Directorate, Tikrit, 34001, Iraq \\ *Corresponding author: e-mail geologistmustafa@gmail.com, tel. +009647707853636
}

\begin{abstract}
Purpose. This study evaluated the reservoir characteristics and determined the formation lithology of Dhiban, Euphrates, and Serikagni in the Hamrin wells (Hr-2 and Hr-9).

Methods. The well logs have used the gamma ray log, the porosity logs, (density, neutron, and sonic logs), and the resistivity logs. The data were converted into digital values by using the Didger program. The formation lithology was determined on the basis of the density, neutron logs, and gamma ray log.

Findings. Lithology consists of limestone, dolomite, dolomitic limestone, and marly limestone with the addition of anhydrite. Petrophysical characteristics, namely, volume of shale, porosity, water saturation, and hydrocarbon saturation were calculated and evaluated. The total volume of water and hydrocarbon for reservoir layers were also determined.

Originality. Dhiban, Euphrates, and Serikagni the formations in the Hamrin field were divided into two potential units, depending on the petrophysical analysis of the well logs in reservoir unit - A(RU-A). Thus, the total thickness of the unit (86.25 m), and average porosity (0.14), the hydrocarbon saturation (0.11), and the volume of shale (14.25). While the Reservoir unit-B (RU-B). The total thickness of the unit (50 m), average porosity (0.09), the hydrocarbon saturation (0.26), and the volume of shale (49).

Practical implications. The RU-A reservoir unit was characterized by high porosity and high hydrocarbon saturation regardless of the thickness in both wells.
\end{abstract}

Keywords: limestone, oil, dolomite, petrophysical, Serikagni, Euphrates, Dhiban

\section{Introduction}

The stratigraphic sequences of Miocene age in Iraq depend on the lithology, fossil content, sedimentary environment, and tectonic effect. Miocene includes elven stratigraphic units: Serikagni, Euphrates, Ghar, Dhiban Anhydrite, Jeribe, Fatha, Nfayil, Injana, Mukdadiya, Govanda Limestone, and Red Bed Series [1]. The early-medium Miocene cycle contains the formations of Ghar, Euphrates, Jeribe, Dhiban, and Serekagni intertwined with each other with the different thicknesses of these formations [2]. The Miocene formations are considered one of the important formations as they form oil reservoirs, the Allas dome within the northern Hamrin field is a good closed reservoir system for preserving and collecting hydrocarbons [3]. The Euphrates Formation contains raw materials represented by Silica, Alumina and Calcite, which it is used in the manufacture of Portland cement according to the Russian classification [4]. The Euphrates formation consists of carbonite rocks with some evaporites deposited in lagoon and shallow environments [5]. The Euphrates Formation consists of limestone, dolomitic limestone, and dolomite deposited in a shallow, sloping, and marshy environment, that is located within the Rimmed plat- form [6]. The problem of research is determined in hydrocarbon reservoir rocks within the Miocene sequence. The importance of the research lies in the recognizing of the reservoir and lithology properties by using the borehole logs for (Dhiban, Euphrates and Serikagni formations) in the Allas dome.The present study aims to determine the lithology and reservoir properties for Dhiban, Euphrates and Serikagni formations in the Allas Dome in the northern Hamrin field.

\section{Material and mthods}

Wells were chosen in North Iraq within the Salah al-Din Governorate in the North Hamrin field (Allas Dome). This field is located at $35 \mathrm{~km}$ northeast of Tikrit city and extends toward southwest Kirkuk and $80 \mathrm{~km}$ between latitudes (422762; 409000) and longitude (3846828; 3859000) as shown in Figure 1. Hamrin-2 (Hr-2) and Hamrin-9 (Hr-9) wells were chosen to examine the formations of Dhiban, Euphrates, Serikagni and subsequently assess the reservoir characteristics and determine of the lithology formations in the study area. The latter is located within the unstable shelf of the foot of a mountainous zone [7]. 


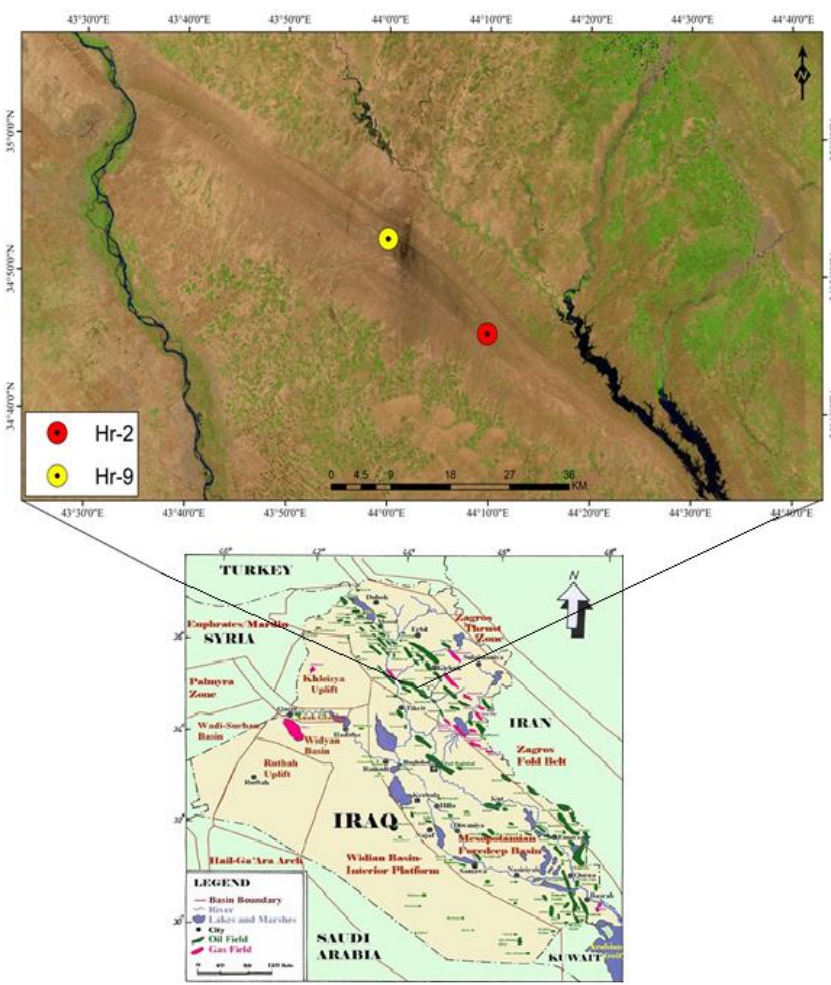

Figure 1. Location of Hamrin Oil Field and the studied Wells

Data were obtained from the NOC [8], [9] to assess the reservoir characteristics and identify the formation lithology (Dhiban, Euphrates, and Serikagni) for $\mathrm{Hr}-2$ and $\mathrm{Hr}-9$ within the Allas Dome in the Northern of Hamrin field. Different types of logs were used to study comprehensively the lithology properties and evaluate the reservoir layers Table 1.

Table 1. Depth and thickness of formations in $\mathrm{Hr}-2$ and $\mathrm{Hr}-9$ wells

\begin{tabular}{cccc}
\hline Well & Formation & Depth interval $(\mathrm{m})$ & Thickness $(\mathrm{m})$ \\
\hline \multirow{3}{*}{$\mathrm{Hr}-2$} & Dhiban & $540.5-607.8$ & 67.3 \\
& Euphrates & $607.8-616.0$ & 8.2 \\
& Serikagni & $616.0-676.0$ & 60.0 \\
\hline \multirow{3}{*}{$\mathrm{Hr}-9$} & Dhiban & $558.0-590.5$ & 32.5 \\
& Euphrates & $590.5-667.5$ & 77.0 \\
& Serikagni & $667.5-695.0$ & 27.5 \\
\hline
\end{tabular}

Various programs were used in drawing logs and lithology. Data were processed using Didger-3, Logplot-7, and Excel. In the study, the used logs are the gamma ray (GR) $\log$, compensated neutron log (CNL), formation density $\log$ (FDC), sonic log (well compensated-type, BHC), caliper, resistance logs, and core data (porosity and permeability).

\section{Results and discussion}

\subsection{Lithology determination from porosity logs}

Porosity logs (density, neutron, and sonic) are significantly affected by the formation lithology, clay content, and gas. The logs for sonic, neutron, and density are typically used interconnectedly rather than alone [10]. Determining the lithology requires readings from the neutron $(\mathrm{ON})$ and density $(\mathrm{Pb}) \operatorname{logs}$ that was obtained from NOC [8], [9]. The points are projected onto a profile prepared by Schlumberger [11] and shown in Figure 2 and 3.

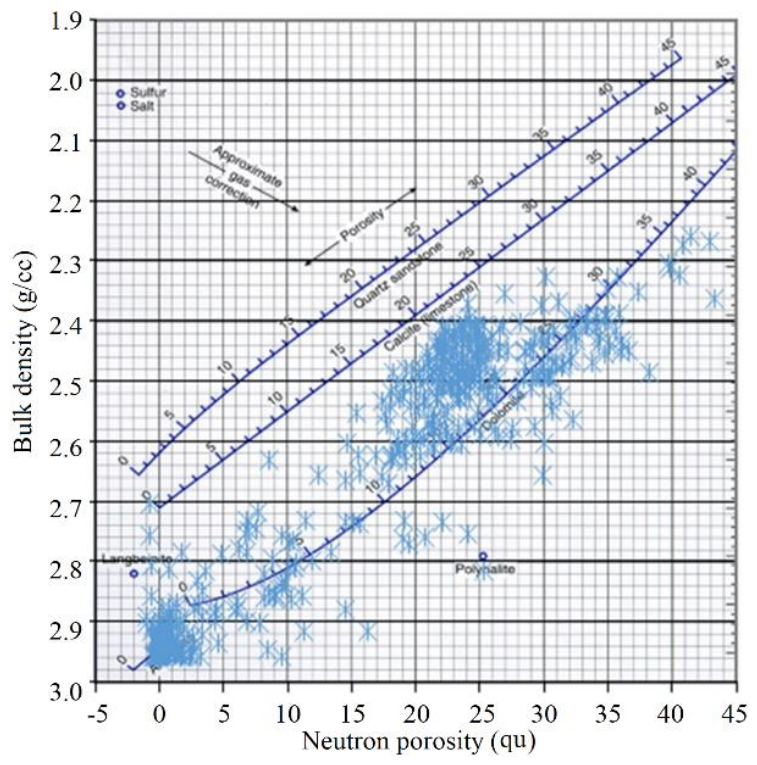

Figure 2. An N-D profile for lithology of $\mathrm{Hr}-2$ well

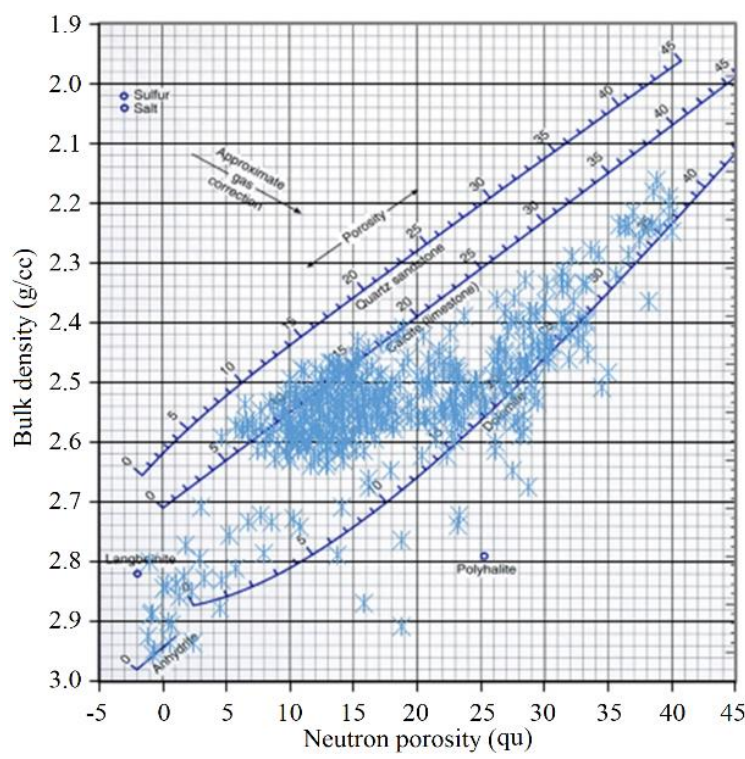

Figure 3. An N-D profile for lithology of $\mathrm{Hr}-9$ well

The majority of the points fall in the limestone range with interventions from dolomite and anhydrite, with a density ranging from 2.16 to $2.95 \mathrm{~g} / \mathrm{cc}$ in the $\mathrm{Hr}-9$ well and from 2.26 to $2.95 \mathrm{~g} / \mathrm{cc}$ in the Hr-2 well. Density, neutron, and GR logs are used to identify the lithology by Logplot-7, Didger3. The Dhiban formation at $\mathrm{Hr}-2$ well has two depths in 540.5-607.8 $\mathrm{m}$ and a thickness of not exceeding $67.3 \mathrm{~m}$. This section consists of permeated anhydrite. Figure 4 shows the thin layers of the dolomitic limestone. By contrast, in the $\mathrm{Hr}$ 9 well, the Dhiban Formation extends from 558.0-590.5 m and with a thickness of not exceeding $32.5 \mathrm{~m}$. This section consists of limestone, dolomite with anhydrite.

The most important fossils identified in this section by the NOC [9] are miliolids with other shell fragments and Gastropoda. The Euphrates formation in the Hr-2 is welldefined between two depths from 607.8-616.0 $\mathrm{m}$ and with a thickness of not exceeding $8.2 \mathrm{~m}$. This section consists of limestone and dolomite (Fig. 4). 


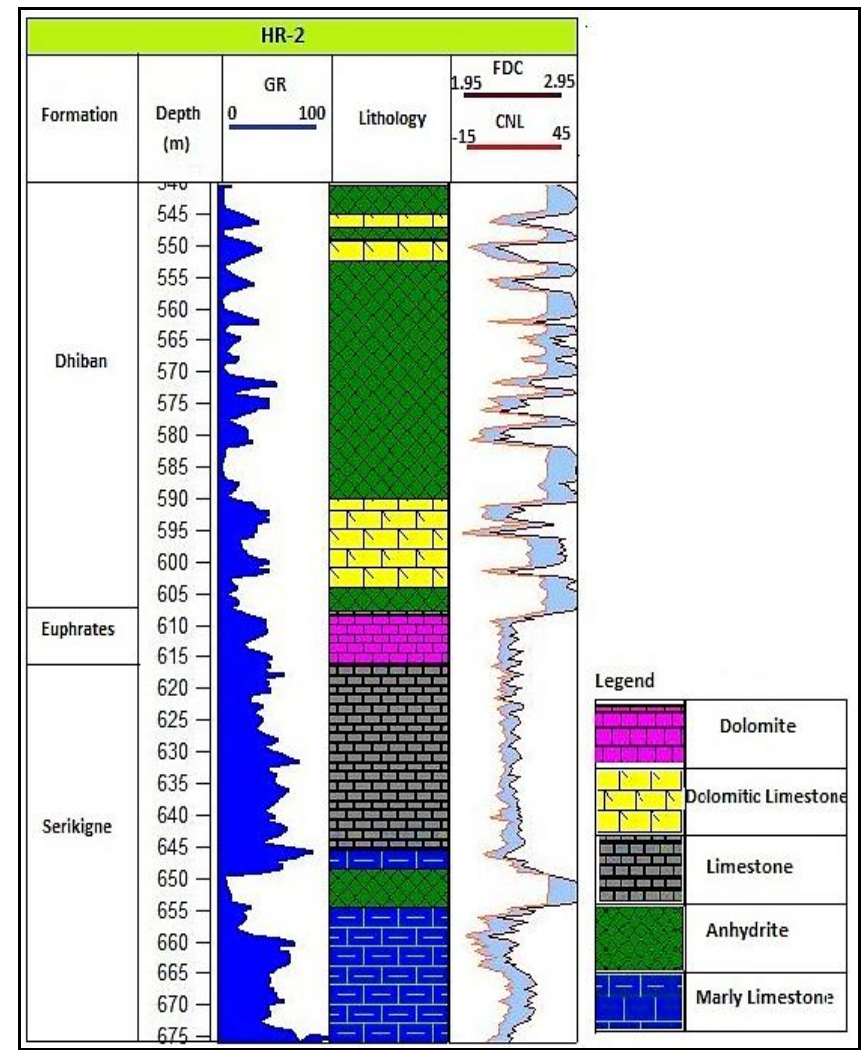

Figure 4. The lithology of the $\mathrm{Hr}-2$ well

By contrast, in the Hr-9 well, the Euphrates formation lies in the depths of 590.5-667.5 m with a thickness of not exceeding $77 \mathrm{~m}$. This formation consists of sequences of limestone, dolomite, and marly limestone with anhydrite (Fig. 5).

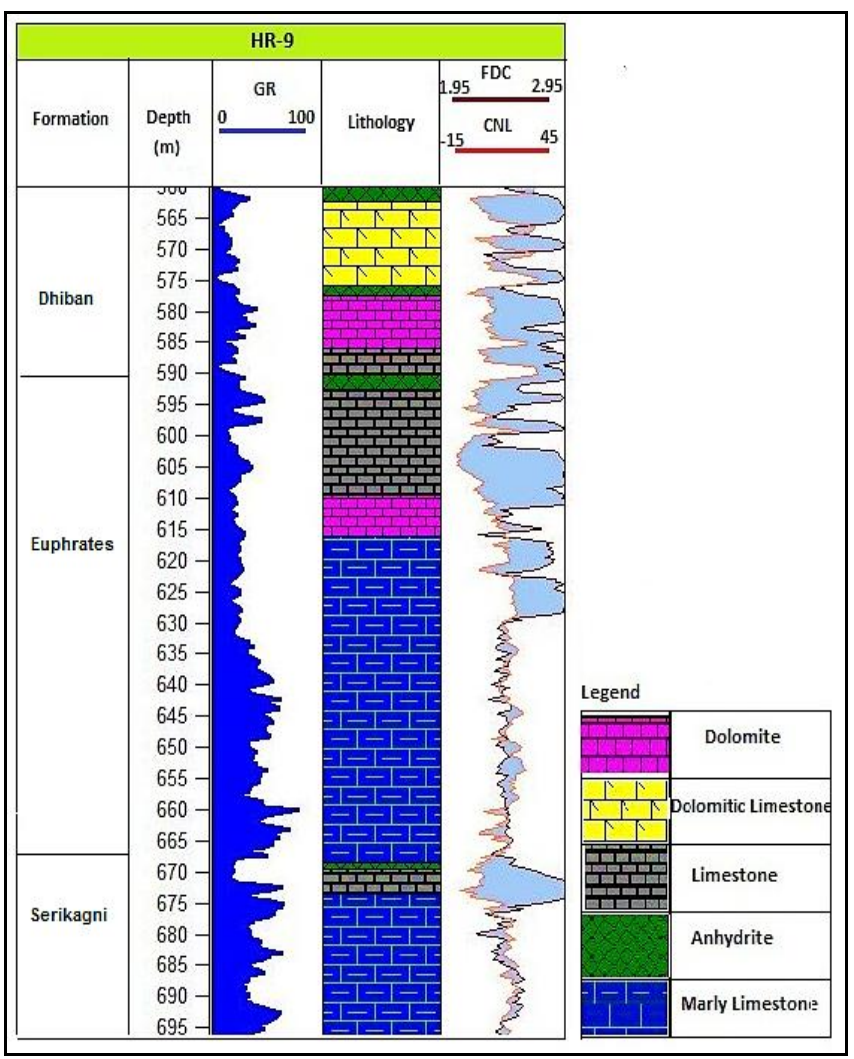

Figure 5. The lithology of the $\mathrm{Hr}-9$ well
The most important fossils in this section are miliolids, Rotalids, and shell fragment NOC [9]. The Serikagni Formation in the Hr-2 well is determined to be between 616 and $676 \mathrm{~m}$ and with a thickness of not exceeding $60 \mathrm{~m}$. This section consists of sequences of limestone and marly limestone with anhydrite (Fig. 4). The most important fossils identified in this section by the NOC [8] were miliolids, shell fragment, and Globigerina. By contrast, this formation is defined in the Hr-9 well between depths of 667.5 and $695 \mathrm{~m}$ with a thickness of not exceeding $60 \mathrm{~m}$. This section consists of sequences of limestone and marly limestone with anhydrite (Fig. 5). The most important fossils in this section identified by NOC [9] are Favrina, Globigerina, bryozoan, Textularia, and other shell fragments.

\subsection{Reservoir properties}

To determine the reservoir properties of the $\mathrm{Hr}-2$ and Hr-9 wells within the study area, the petrophysical properties of the reservoir should be recognized and evaluated.

\subsubsection{Volume of shale}

The GR $\log$ is used to determine and calculate the volume of shale $\left(V_{s h}\right)$, because the GR log responds to the radioactive materials stationed in the shale rock. it is imperative that the gamma ray index IGR, determined by using equation of [12]:

$$
I G R=\frac{\left(G R_{\log }-G R_{\min }\right)}{\left(G R_{\max }-G R_{\min }\right)},
$$

where:

$G R_{\log }$ - gamma ray reading of formation;

$G R_{\min }$ - minimum gamma ray reading (clean sand or carbonate);

$G R_{\max }$ - maximum gamma ray reading (shale).

The equation of [13] for older rocks was used to determine the shale volume shown in Table 2:

$V_{s h}=0.33 \cdot(2 \cdot(2 \cdot I G R)-1)$.

\subsubsection{Porosity}

Porosity is the ratio between the volume of voids in the rock to the total size of the rock. Porosity can be classified as primary and secondary porosities depending on the time of its formation [14]. Several methods are used to calculate porosity either from the sonic $\log$ or from the density and neutron logs of shale free zone [15]. In depths where the ratio exceeds the volume of shale $10 \%$, the logs (sonic, density and neutron) will record high porosity [16] is corrected to remove the effect of (11) while neutron log its values are corrected for depths of the recorded $V_{s h}$ greater than $10 \%$ [17] shown in Table 2.

$$
\varnothing S_{c o r r}=\frac{\Delta t \log -\Delta t m a}{\Delta t f l-\Delta t m a}-\left(\frac{\Delta t \log -\Delta t m a}{\Delta t f l-\Delta t m a}\right) \cdot V_{s h},
$$

where:

$\emptyset S_{\text {corr }}$ - corrected sonic porosity;

$\Delta t \log$ - interval transit time in the formation;

$\Delta t m a$ - interval transit time in the matrix;

$\Delta t f l$ - interval transit time in the fluid in the formation;

$V_{s h}$ - volume of shale. 
Table 2. Shows petrophysical interpretations of the wells of study area

\begin{tabular}{cccccccc}
\hline & Well & & \multicolumn{3}{c}{ Hr-2 } & \multicolumn{3}{c}{ Hr-9 } \\
\hline \multirow{2}{*}{ Depth } & & $540.5-607.8$ & $607.8-616.0$ & $616.0-676.0$ & $558.0-590.5$ & $590.5-667.5$ & $667.5-695.0$ \\
\hline \multirow{2}{*}{ Formation } & Dhiba & Euphrates & Serikagni & Dhiba & Euphrates & Serikagni \\
\hline \multirow{2}{*}{$V_{s h}$} & Min. & 0.47 & 3.40 & 1.37 & 0.32 & 4.10 & 6.98 \\
& Max. & 58.44 & 46.22 & 71.9 & 30.54 & 62.5 & 98.2 \\
\hline \multirow{2}{*}{$\Theta D$} & Min. & -0.14 & -0.13 & -0.51 & -0.11 & -0.11 & -0.08 \\
& Max. & 0.20 & 0.15 & 0.21 & 0.19 & 0.27 & 0.17 \\
\hline \multirow{2}{*}{$\Theta N$} & Min. & -0.009 & 0.012 & -0.95 & -0.011 & -0.15 & 0.0028 \\
& Max. & 0.34 & 0.21 & 0.34 & 0.31 & 0.35 & 0.31 \\
\hline \multirow{2}{*}{$\Theta S$} & Min. & -0.76 & -0.62 & -0.660 & -1.09 & -0.960 & -0.93 \\
& Max. & -0.05 & -0.099 & 2.32 & -0.03 & 0.46 & 0.91 \\
\hline \multirow{2}{*}{$\Theta_{N-D}$} & Min. & 0.032 & 0.051 & 0.0096 & 0.026 & 0.0089 & 0.0022 \\
& Max. & 0.27 & 0.18 & 0.766 & 0.24 & 0.30 & 0.23 \\
\hline \multirow{2}{*}{$S_{w}$} & Min. & 0.022 & 0.040 & 0.011 & 0.022 & 0.020 & 0.027 \\
& Max. & 0.183 & 0.13 & 0.12 & 0.18 & 0.84 & 0.36 \\
\hline \multirow{2}{*}{$S_{x o}$} & Min. & 0.062 & 0.10 & 0.028 & 0.069 & 0.059 & 0.075 \\
& Max. & 0.45 & 0.36 & 0.24 & 0.53 & 0.23 & 0.91 \\
\hline \multirow{2}{*}{$B_{v w}$} & Min. & 0.0049 & 0.0064 & 0.0050 & 0.0050 & 0.005 & 0.0062 \\
& Max. & 0.0089 & 0.0089 & 0.010 & 0.0086 & 0.007 & 0.0086 \\
\hline \multirow{2}{*}{$B_{v x o}$} & Min. & 0.013 & 0.018 & 0.014 & 0.014 & 0.015 & 0.017 \\
& Max. & 0.025 & 0.025 & 0.024 & 0.022 & 0.022 & 0.023 \\
\hline \multirow{2}{*}{$B_{v o}$} & Min. & 0.026 & 0.044 & -0089 & 0.021 & 0.0013 & -0.0059 \\
& Max. & 0.27 & 0.178 & 0.75 & 0.23 & 0.30 & 0.23 \\
\hline
\end{tabular}

$\varnothing D_{c o r r}=\varnothing D-\left(V_{s h} \cdot \varnothing D_{s h}\right)$

where:

$\varnothing D_{\text {corr }}$ - corrected porosity is derived from density $\log$ for unclean rocks;

$\varnothing D_{s h}$ - density porosity for shale.

$$
\varnothing N_{c o r r}=\varnothing N-\left(V_{s h} \cdot \varnothing N_{s h}\right),
$$

where:

$\emptyset N_{\text {corr }}$ - corrected porosity is derived from Neutron $\log$ for no clean rocks;

$\varnothing N_{s h}-$ Neutron porosity for shale.

In addition, the total and secondary porosities can be calculated [18] shown in Table 2.

$\varnothing_{N-D}=\frac{(\varnothing N+\varnothing D)}{2}$.

The effective porosity:

$S P I=\varnothing_{N-D}-\varnothing S_{c o r r}$.

\subsubsection{Water and hydrocarbon saturation}

Water saturation $S_{w}$ is the ratio between the volume of voids filled with water to the total volume of voids of the rock. The hydrocarbon saturation $S_{h}$ is the remainder of the volume of voids in the rock can be calculated [19]. $S_{w}$ is calculated in the range not contaminated by mud and the $S_{w}$ contaminated by mud $S_{x o}$ to determine the movement of hydrocarbons [20]. Table 2 represents the lower and upper limits of $S_{w}$. The total volume of water is calculated in the noncontaminated $B_{v w}$ range and $B_{v x o}$ contaminated range with mud.

The total volume of hydrocarbons $B_{o v}$, which include moving hydrocarbons $M_{o s}$ and nonmoving hydrocarbons, is calculated [20], [21] as shown in Table 2.

$S_{w}=\left(F \cdot \frac{R_{w}}{R_{t}}\right)^{\frac{1}{n}}$.
Water saturation in the invaded zone $\left(S_{x o}\right)$ can be simply calculated from the same equation above by replacing $R_{w}$ with $R_{m f}$ (mud filtrate resistivity available from well log headers) and $R_{t}$ with $R_{x o}$ (measured resistivity of the invaded zone):

$S_{x o}=\left(F \cdot \frac{R_{m f}}{R_{x o}}\right)^{\frac{1}{n}}$.

Than can be calculating the hydrocarbon saturation, by using the following equation:

$S_{h}=1-S_{w}$.

Moveable hydrocarbon saturation was calculated by using following equation:

$M_{o s}=S_{x o}-S_{w}$.

Whereas total hydrocarbon volume was calculated from Schlumberger (1987) as follows equation:

$B_{v o}=S_{h} \cdot \varnothing_{N-D}$.

\subsubsection{Calculation of pore-throat structure}

Pore-throat structures are defined as passages that facilitate the passage of fluid through the voids or from one pore to another [22]. These structures are calculated by the injection of 35\% mercury saturation [17]. The drawn relationship between porosity and permeability is obtained from the core analysis of NOC [8], [9]. The points that fall on a sinelogarithmic paper characterize the pore-throat structure. Figure 6 and 7 show the most important types of pore throats in the formation rocks of Dhiban, Euphrates, and Serikagni within the Hr-2 and Hr-9 wells.

\subsubsection{Calculation of reservoir quality index and flow zone RQI, FZI}

Depending on the data obtained from NOC [8], [9] the points were put it onto a logarithmic profile depend on the porosity values (ZØ) and the flow quality factor (RQI) values [23]. 


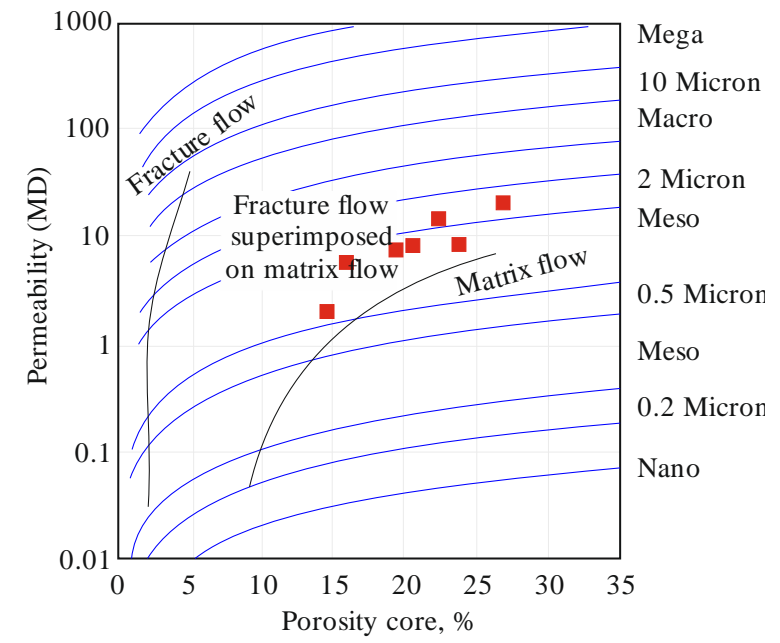

Figure 6. Pores throat type for $\mathrm{Hr}-2$ well at $35 \%$ mercury saturation

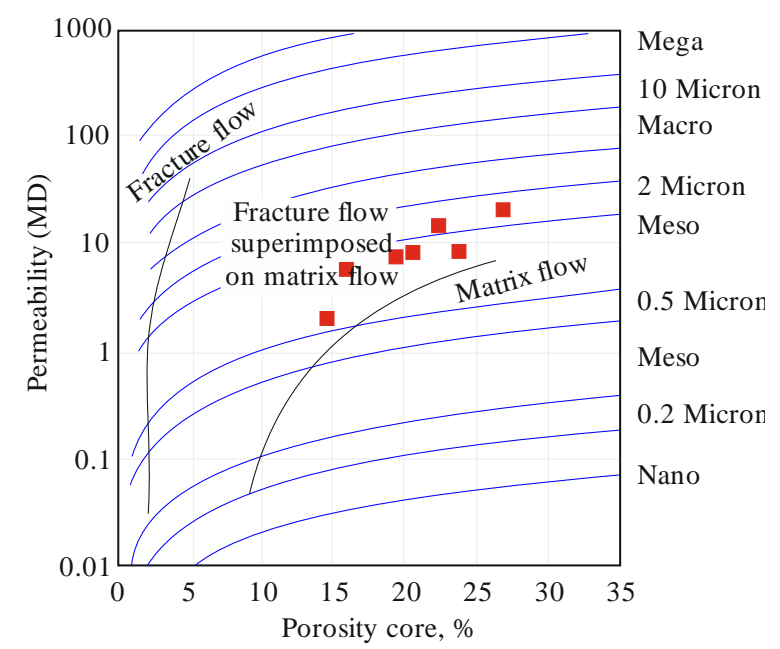

Figure 7. Pores throat type for $\mathrm{Hr}-9$ well at $35 \%$ mercury saturation

A straight line was drawn at an angle of inclination (1). permeability relationship with porosity values for evaluation of reservoir quality [24]. It was found from the current study of $\mathrm{Hr}-2$ and $\mathrm{Hr}-9$ wells that the most common porosities in the rocks of the study area formations are Intrapartical, Moldic, Intercrystalline, Vuggy and Interpartical as shown in Figure 8 and 9. This indicates that the type pores that control on quality of the tank of one type to the pores throat type, because they form pathways for the movement of hydrocarbons.

\subsubsection{Reservoir units}

Through the petrophysical analysis of the reservoir properties by using logs for the wells of the study area (Table 2). Depending on effective porosity, oil saturation and volume of shale can be divided the formations of study area into two reservoir units (RU-A and RU-B) as shown in Figure 10 and 11.

1. Reservoir unit (RU-A): the thickness of this unit ranges $(89.5 \mathrm{~m})$ at the $\mathrm{Hr}-2$ well east of the Allas Dome and $(83 \mathrm{~m})$ at the Hr-9 well located to the west of the dome as shown in Figure 10 and 11 , this unit is characterized by a porosity is between (0.03-0.28) at a range of (0.12) at the $\mathrm{Hr}-2$ well, while the porosity in this unit is between (0.02-0.3) at a range of $(0.15)$ at the Hr-9 well, while the oil saturation of this unit is between $(0.038-0.36)$ at a range of $(0.11)$.

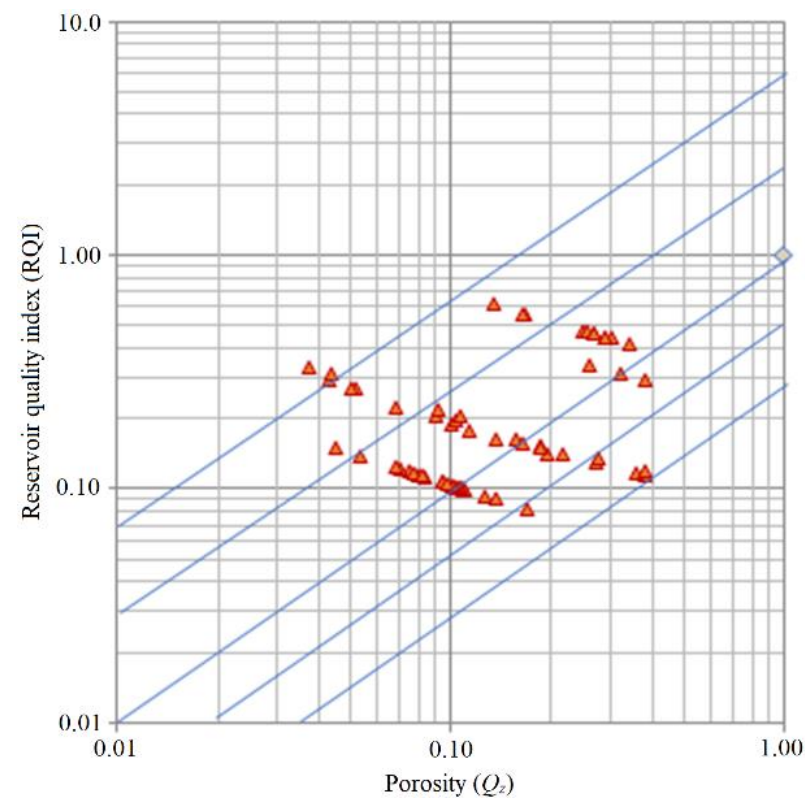

Figure 8. Fluid flow for $\mathrm{Hr}$-2 well

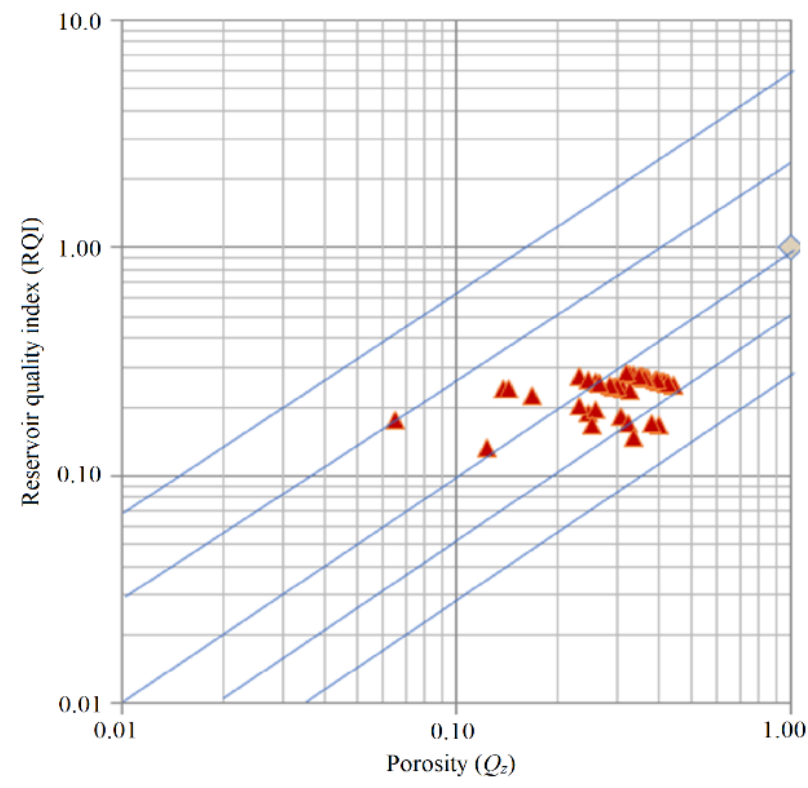

Figure 9. Fluid flow for $\mathrm{Hr}$-9 well

At the Hr-2 well, at the Hr-9 well, oil saturation is between (0.04-0.3) at a range of (0.10) while the volume of shale of this unit is between $(0.4-77.3 \%)$ at a range of $(15.5 \%)$ at the $\mathrm{Hr}-2$ while the volume of shale in the well $\mathrm{Hr}$ 9 is between $(0.5-66 \%)$ at a range (13\%).

2. Reservoir unit (RU-B): the thickness of this unit (46 m) at well $\mathrm{Hr}-2$ and thickness (54 m) at well $\mathrm{Hr}-9$ as shown in Figure 10 and 11. This unit is characterized by porosity is between $(0.0009-0.766)$ at a range $(0.10)$ at the $\mathrm{Hr}-2$ well while at the $\mathrm{Hr}-9$ well the porosity is between $(0.002-0.23)$ at a range $(0.08)$ as it is characterized by oil saturation at the well $\mathrm{Hr}-2$ is between (0.01-0.4) at a range $(0.32)$ at the $\mathrm{Hr}-9$ well, the oil saturation is between (0.04-5.49) at a range (0.25), the volume of shale at the $\mathrm{Hr}-2$ well is between (1.4-98\%) at a range (58\%) while at the Hr-9 well, the volume of shale is between $(6.98-99 \%)$ at a range $(40 \%)$. 


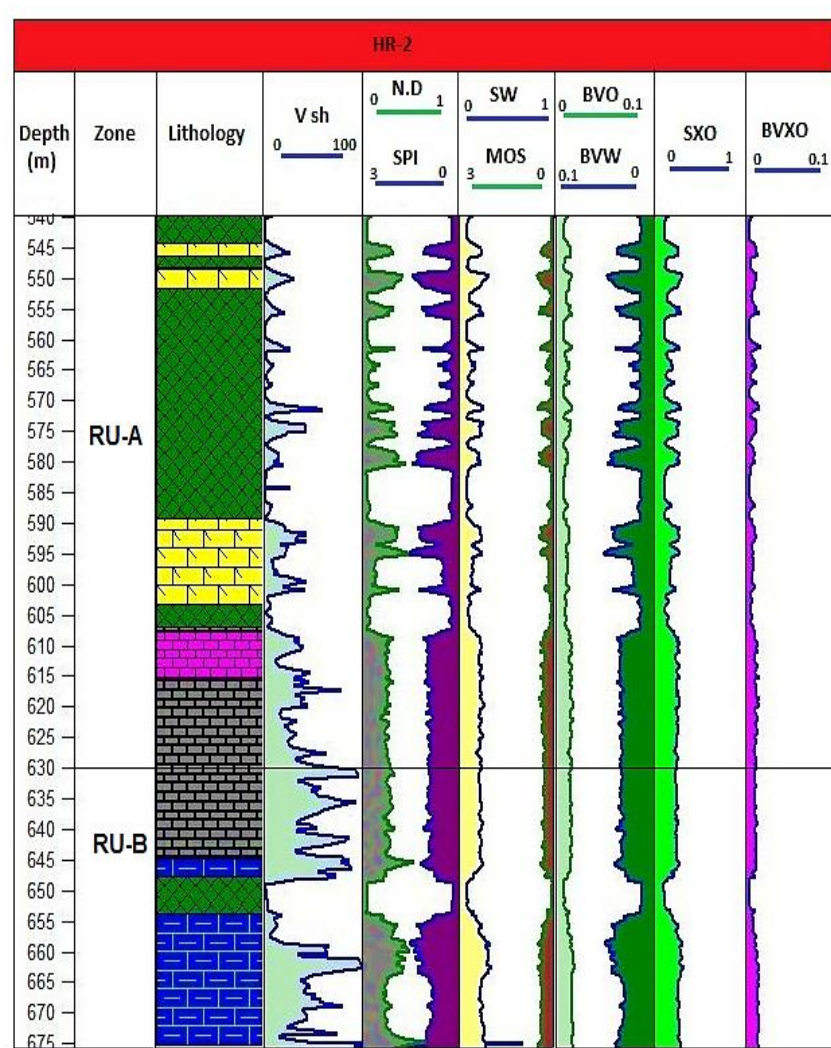

Figure 10. Interpretations of logs for $\mathrm{Hr}-2$ well

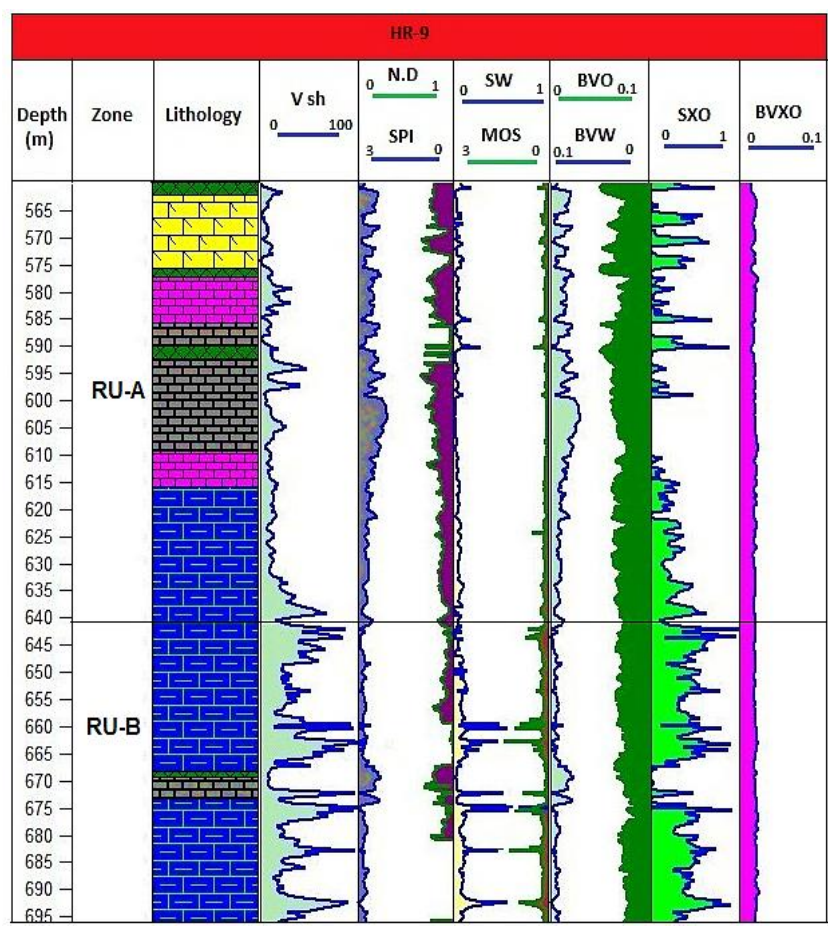

Figure 11. Interpretations of logs for $\mathrm{Hr}-9$ well

\section{Conclusions}

Depending on the petrophysical analysis of well logs of the Dhiban, Euphrates, and Serikagni formations in the Hamrin wells (Hamrin-2 (Hr-2) and Hamrin-9 (Hr-9)):

1. The lithology includes limestone, dolomite, dolomitic limestone, and marly limestone with anhydrite of formations rocks.
2. The formations can be divided into two reservoir units (RU-A and RU-B) according to the effective porosity, oil saturation, and volume of shale. Reservoir unit $-\mathrm{A}$ (RU-A) is: the total thickness of the unit $(86.25 \mathrm{~m})$, average porosity (0.14), hydrocarbon saturation $(0.11)$, and the volume of shale is (14.25). While Reservoir unit-B (RU-B) is: the total thickness of the unit $(50 \mathrm{~m})$, average porosity $(0.09)$, the hydrocarbon saturation (0.26), and the volume of shale (49). The best reservoir unit is RU-A, regardless of the heterogeneity of the thickness of both wells.

3 . There are several types of porosity associated with formations, they are diagnosed throughout the profile relationship between porosity values (ZØ) and the Reservoir quality index (RQI), such as: Intrapartical, Moldic, Intercrystalline, Vuggy and Interpartical. While the Pore-throat type is dominant mesopores and macropores.

\section{Acknowledgements}

Thanks to the North Oil Company in Iraq, Department of Geology, for their support in contributing to complete this research.

\section{References}

[1] Sissakian, V., Karim, S., Al-Kubaisy, K., Al-Ansari, N., \& Knutsson, S. (2016). The Miocene sequence in Iraq, a review and discussion on the stratigraphy, paleogeography and economic potential. Journal of Earth Sciences and Geotechnical Engineering, 6(3), 271-317.

[2] Ameen Lawa, F.A., \& Ghafur, A.A. (2015). Sequence stratigraphy and biostratigraphy of the prolific late Eocene, Oligocene and early Miocene carbonates from Zagros fold-thrust belt in Kurdistan region. Arabian Journal of Geosciences, 8(10), 8143-8174. https://doi.org/10.1007/s12517-015-1817-4

[3] Al-Sulaiman, F.A., Al Fahdawi, S.S.A., \& Al Qaisy, S.A.S. (2017). Detection of structural control on formation water quality, in Hemrin oilfield, Northern Iraq, using lineament analysis and hydrochemical data. Tikrit Journal of Pure Science, 22(2), 145-158.

[4] Awadh, S.M., \& Al-Owaidi, M.R., (2020). Application of triangles method for quantitative estimation of marl reserve in Euphrates formation, middle of Iraq. Iraqi Geological Journal, 53(2A), 35-49. https://doi.org/10.46717/igj.53.2a.3rw-2020.08.03

[5] Hussein, D., Collier, R., Lawrence, J.A., Rashid, F., Glover, P.W.J., Lorinczi, P., \& Baban, D.H. (2017). Stratigraphic correlation and paleoenvironmental analysis of the hydrocarbon-bearing Early Miocene Euphrates and Jeribe formations in the Zagros folded-thrust belt. Arabian Journal of Geosciences, 10(24), 543. https://doi.org/10.1007/s12517-017$\underline{3342-0}$

[6] Mahammed, M.H., \& Nasser, M.E. (2018). Facies Analysis and Geological modeling of Euphrates Formation in Ajeel Oil Field, Northern Iraq. Iraqi Journal of Science, 59(4B), 2065-2079. https://doi.org/10.24996/ijs.2018.59.4b.12

[7] Jassim, S.Z., \& Goff, J.C. (2006). Geology of Iraq. Brno, Czech Republic: Dolin, Prague and Moravian Museum.

[8] Final geological report of wells Hamrin well-2 (Hr-2). (1976). Iraq: North Oil Company.

[9] Final geological report of wells Hamrin well-9 (Hr-9). (1982). Iraq: North Oil Company.

[10] Rider, M. (2002). The geological interpretation of well logs. Aberdeen and Sutherland, United Kingdom: Rider French Consulting Ltd.

[11] Log interpretation chart. (1988). Huston, United States: Schlumberger Educational Services.

[12] Log interpretation. Volume I. Principles. (1974). New York, United States: Schlumberger Limited.

[13] Dresser, A. (1979). Log interpretation charts. Houston, United States: Dresser Industries Inc.

[14] Selley, R.C. (1998). Elements of petroleum geology. Oxford, United Kingdom: Gulf Professional Publishing.

[15] George, A., \& Charles, G. (1982). Basic well log analysis for geologist. Tulsa, United States: American Association of Petroleum Geologist.

[16] Asquith, G.B., \& Gibso, C.R. (1982). ME 3: Basic well log analysis for geologists. Tulsa, United States: American Association of Petroleum Geologists. https://doi.org/10.1306/99a4d0a3-3318-11d7-8649000102c1865d 
[17] Tiab, D., \& Donaldson, E. (2012). Petrophysics, Third edition. Tulsa, United States: Gulf Professional Publishing.

[18] Log interpretation charts. (1997). Huston, United States: Schlumberger Wireline Testing.

[19] Archie, G.E. (1950). Introduction to petrophysics of reservoir rocks. AAPG Bulletin, 34(5), 943-961. https://doi.org/10.1306/3d933f62$16 \mathrm{~b} 1-11 \mathrm{~d} 7-8645000102 \mathrm{c} 1865 \mathrm{~d}$

[20] Log interpretation principles/application. (1989). Huston, United States: Schlumberger Wireline Testing.

[21] Log interpretation charts. (1987). Huston, United States: Schlumberger Educational Services.
[22] Alden, J.M., \& Stephen, T. (1997). Characterization of petrophysical flow units in carbonate reservoirs. AAPG Bulletin, 81(5), 734-759. https://doi.org/10.1306/522b482f-1727-11d7-8645000102c1865d

[23] Orodu, O.D., Tang, Z., \& Fei, Q. (2009). Hydraulic (flow) unit determination and permeability prediction: A case study of Block Shen-95, Liaohe Oilfield, North-East China. Journal of Applied Sciences, 9(10), 1801-1816. https://doi.org/10.3923/jas.2009.1801.1816

[24] Abdi, F., Kamali, M., Aleali, M., \& Kadkhodaie, A. (2020). Study of hydraulic flow units using static modeling in upper Surmeh formation (Arab) in one of the Oil Fields, Persian Gulf. Kuwait Journal of Science, 47(1), 103-112.

Характеристика нафтогазового пласта міоценового періоду в куполі Аллас, Хамрінської антикліналі, Північний Ірак

\section{Д.Т. Фадхіл, В.А. Йонус, М.А. Тіяб}

Мета. Визначення та оцінка характеристик літології нафтогазових пластів Дібана, Євфрату і Серікагні за свердловинами Хамрін на основі сучасних геофізичних методів та цифрових технологій.

Методи. У дослідженні використовувались дані свердловин $\mathrm{Hr}-2$ та Hr-9 у провінції Салах аль-Дін на родовищі Північний Хамрін. Для моніторингу свердловин використовувалися дані гамма-каротажу (GR), компенсованого нейтронного каротажу (CNL), каротажу щільності пласта (FDC), звукового каротажу (свердловинний каротаж, BHC), кавернометрії, каротаж опору та дані кернів (пористість і проникність). Дані були перетворені в цифрові значення для побудови каротажних діаграм і літології за допомогою програм Didger-3, Logplot-7 та Excel. Літологію пласта визначали на основі щільнісного гама каротажу, нейтронного каротажу та журналів нейтронів і діаграми гамма-каротажу.

Результати. Встановлено, що літологія нафтогазових пластів складається з вапняку, доломіту, доломітового вапняку та мергелистого вапняку з додаванням ангідриту. Розраховані та оцінені петрофізичні характеристики, а саме: обсяг сланців, пористість, насиченість водою та насиченість вуглеводнями. Визначено загальний об'єм води та вуглеводнів для шарів пласта. Запропоновано нафтогазові утворення родовища Хамрін поділити на дві потенційні одиниці залежно від петрофізичних даних свердловин у пластовій частині - A (RU-A). Визначено загальну потужність покладу - 86.25 м, середню пористість - 0.14, насиченість вуглеводнями 0.11 та обсяг сланців - 14.25. В той же час, у пластовій частині - B (RU-B) загальна потужність покладу склала 50 м, середня пористість -0.09 , насиченість вуглеводнями - 0.26 , а обсяг сланців -49 .

Наукова новизна. Вперше для умов нафтогазових пластів Дібан, Свфрат та Серікагні виявлені їх петрофізичні характеристики, фізико-механічні властивості та особливості літологічної будови масиву.

Практичне значення. Врахування виявленої високої пористості та насиченості пластової частини RU-A дозволить вносити корективи у технологічні параметри розробки нафтових родовищ для підвищення ефективності видобутку.

Ключові слова: вапняк, нафта, доломіт, петрофізичний, Серікагні, Свфрат, Дібан

\section{Характеристика нефтегазового пласта миоценовогой периода в куполе Аллас, Хамринской антиклинали, Северный Ирак}

\section{Д.Т. Фадхил, В.А. Йонус, М.А. Тияб}

Цель. Определение и оценка характеристик литологии нефтегазовых пластов Дибана, Евфрата и Серикагни по скважинам Хамрин на основе современных геофизических методов и цифровых технологий.

Методика. В исследовании использовались данные скважин $\mathrm{Hr}-2$ и $\mathrm{Hr}-9$ в провинции Салах аль-Дин на месторождении Северный Хамрин. Для мониторинга скважин использовались данные гамма-каротажа (GR), компенсированного нейтронного каротажа $(\mathrm{CNL})$, каротажа плотности пласта (FDC), звукового каротажа (скважинный каротаж, ВНC), кавернометрия, каротаж сопротивления и данные кернов (пористость и проницаемость). Данные были преобразованы в цифровые значения для построения каротажных диаграмм и литологии с помощью программ Didger-3, Logplot-7 и Excel. Литологии пласта определяли на основе плотностного гамма каротажа, нейтронного каротажа и журналов нейтронов и диаграммы гамма-каротажа.

Результаты. Установлено, что литология нефтегазовых пластов состоит из известняка, доломита, доломитового известняка и мергелистого известняка с добавлением ангидрита. Рассчитаны и оценены петрофизические характеристики, а именно: объем сланцев, пористость, насыщенность водой и насыщенность углеводородами. Определен общий объем воды и углеводородов для слоев пласта. Предложено нефтегазовые образования месторождения Хамрин разделить на две потенциальные единицы в зависимости от петрофизических данных скважин в пластовой части - A (RU-A). Определена общая мощность залежи - 86.25 м, средняя пористость -0.14 , насыщенность углеводородами - 0.11 и объем сланцев -14.25 . В то же время, в пластовой части - B (RU-B) общая мощность залежи составила 50 м, средняя пористость -0.09 , насыщенность углеводородами -0.26 , а объем сланцев -49 .

Научная новизна. Впервые для условий нефтегазовых пластов Дибан, Евфрат и Серикагни выявлены их петрофизические характеристики, физико-механические свойства и особенности литологического строения массива.

Практическая значимость. Учет выявленной высокой пористости и насыщенности пластовой части RU-A позволит вносить коррективы в технологические параметры разработки нефтегазовых месторождений для повышения эффективности добычи.

Ключевые слова: известняк, нефть, доломит, петрофизический, Серикагни, Евфрат, Дибан

\section{Article info}

Received: 14 April 2020

Accepted: 26 October 2020

Available online: 7 November 2020 